\title{
TABUS LINGÜÍSTICOS
}

\section{R. F. Mansur Guérios.}

(Continuação)

\section{TABUS EM NOMES DE PARENTES - Pareceria natural} que a proibição fôsse apenas a estranhos ou a estrangeiros, mas, na realidade, há tabus antroponímicos entre os membros de uma mesma familia, unidos pelo sangue ou apenas pelo casamento. A proibição estende-se também às designações dos graus de parentesco, e atinge não só as palavras ordinárias, substantivos comuns, que se assemelham aos antropônimos, senão até aquelas dotadas de uma sílaba igual.

Muitas interdições desta natureza são de caráter moral e sentimental, isto é, evitam-se as designações de parentela por temor ao incesto, e, em presença de estranhos para não dar mostra de qualquer efeminação, ou para não melindrar o presumivel recato dos circunstantes com expressões de carinho, dotadas de grande afetividade.

Os llas (Rodésia setentrional) (39) não permitem a alguém proferir o nome de sua espôsa, nem de seu pai, de sua mãe ou dos sogros, e tão pouco o dos irmãos e irmãs da espôsa, ou dos irmãos do pai. Assim também deve ela observar. $O$ marido não profere o nome da mulher, nem esta o do marido. Se, p. ex., entre os llas, um homem fôr chamado Shamatanga, "feijão", e sua mulher Kabubi, "cogumelo", ela não deve falar de melōes

(39) D. Westermann, "Tabu und Sprache in Afrika" in "Forschungen und "Fortschritte", n. 5, Berlim, 10-2-1940. - O conjunto das designaçōes permitidas entre as mulheres zulus $e$ entre as cafres tem o nome de isihlonipa, "lingua das que tèm vergonha" (C. Tagliavini, "Modificazioni del Linguaggio nella Parlata delle Donne" in "Scritti in Onore di A. Trombetti", 1938, p. 129. 
evita o espôso o nome do cogumelo, ao qual dá a denominação "minha espôsa". Os filhos de ambos chamarão aos melões madirá, p. ex., malúmi, ángu, i. é, "meus maridos", e igualmente com o seu nome usual matanga (por causa da semelhança), mas sediata, "parentes de nome de nosso pai", e aos cogumelos busediama, "parentes de nome de nossa mãe".

Em tôda a África há severas punições aos sogros e noras, aos genros e sogras, por qualquer relação entre si, e que se deve evitar por incestuosa (39).

Com os Zulus, o mais grave juramento que a mulher casada possa prestar, é dizer — mamezala! — "meu sogro!" Isto significa: "Se eu faltar à verdade, então quero ser uma que tenha relação sexual com meu sogro". Para fugir a tamanha desonra, sogro e nora, genro e sogra devem evitar-se de qualquer modo, e isto mesmo além da morte.

A nora não pode trabalhar no campo onde perto se acha sepultado o sogro; nem se the permite comer dos frutos dai. Evita o nome do sogro e dos irmãos dêste, que vivos ou mortos, e ela não pode sequer proferir palavra símile ou de sílaba principal igual. E vale isto igualmente para a sogra em relaçāo ao genro. Chama-se êle, p. ex., Umánzi, "água", a sogra evitará todos os vocábulos em que se apresenta mánzi, "água”, e todos os complexos fônicos semelhantes. E se ela possuir mais genros, uma série de palavras the será proibida e as quais deverão ser substituídas por outras. Para mánzi, p. ex., dirá mayiwa ou mandámbi, amayilinda ou amada ou amakkubane, as quais só têm de comum o prefixo de classe ama-, ma-, "água".

Para designar o marido, a zulu tem o expediente das perífrases, como, p. ex., "pai de seu filho" (J. G. Frazer), ou, então, locuções antroponímicas em que entram palavras como "touro". "vaca", "leão", etc (Mário Pei).

Origina-se, dêste modo, uma verdadeira linguagem das muIheres, que, na estrutura, é a mesma da da tribo, mas enriquecida de substantivos e mesmo de verbos, os quais, fora do âmbito familial, são inteiramente incompreensíveis. Em contraposição, os homens da tribo Purrá (Serra Leone, costa ocidental da Africa) 
mantém uma sociedade secreta cujos membros empregam, nas cerimônias, uma linguagem especial, esotérica, desconhecida às mulheres (40).

As mulheres sérvias e ucrainas é proibido mencionar o nome do marido; com freqüência empregam o pronome "êle" (Havers).

Vejamos os tabus lingüisticos de parentela com outros povos ou tribos (4l):

Niassalândia setentrional - a mulher evita o nome de seu marido e até emprega sinônimos dêsse nome. Se proferir o verdadeiro, causar-lhe-á desgraça e impedirá de ter filho.

Condes (margens do lago Niassa) - a casada não pronuncia o nome do sogro: não the fala, nem mesmo pode vê-lo.

Boreas e Bogos (Átrica oriental) - a espôsa evita o nome do marido.

Haussas (África ocidental) — os pais do primogênito não o citam; evitam mesmo falar-ihe em presença de outras pessoas.

India meridional - as mulheres crêem pronunciar o nome de seu marido, em sonho, leva-lo-iam à morte prematura; evitam o nome de seus pais, dos sogros, cunhados e cunhadas.

Todas (sopé de Nilgiri, sul da India) - é proibido dizer o nome do irmāo de sua mãe, do avô, da avó, do sogro, da sogra. Êsses tabus são mais severos após a morte dêles.

Esgaus (tribo carem da Birmânia) — as crianças nunca pronunciam o nome de seus pais.

Ainos (norte da ilha de lesso, Japão, e ilhas Sacalinas) as mulheres não proferem o nome do marido; pronunciá-lo equivaleria a matá-lo.

Quirguizes (Rússia oriental) — as mulheres não dizem o nome dos parentes de seu marido, dos mais velhos que êle, nem mesmo as palavras homófonas ou quase. Se um dos parentes se

(40) M. Pei, o. c. p. 249.

(41) Resumimos a vasta compilação encerrada nas páginas de lames George Frazer - "Tabou et les Périls de l'Áme" — trad. de Henri Peyre, Paris, 1927. 
chama "carneiro", elas evitam o nome comum e o substituem pela perifrase "os animaizinhos que balem".

Batas ou Bataques (Samatra) - não pronunciam o seu nome, de seus pais e avós. Um amigo responde por êles. Não declaram o nome de sua mulher, da cunhada, do genro. E' proibido à mulher dizer o nome do homem que esposou a filha.

Daiaques (Bornéu) - Se, p. ex., uma pessoa da família se chama Bitang, "estrêla", esta será denominada pariana, seu sinônimo. Se se chama Bulan, "lua", esta passa a ser penala.

Daiaques (da costa de Sarauaque, Bornéu) - é vedado ao homem casado pronunciar o nome do sogro, ou da sogra. Têm ainda como sogro e sogra o pai e a mãe de seus cunhados e cunhadas, e mesmo o pai e a mãe de todos os seus primos. Por causa dêsses antropônimos tabuizados, evitam também os correspondentes comuns, de que aquêles se derivaram.

Sonda (uma das ithas do arquipélago malaio) - seria arruinada certa colheita, se um homem viesse a mencionar o nome do pai ou da mãe.

Nufuras (Nova Guiné Holandesa) — há proibição de proferir o nome de pessoas ligadas pelo casamento. Tal se verificava desde logo após o noivado. Ambas as famílias obedecem à tal proibição.

Se acontece que alguém pronuncia inadvertidamente um nome tabu, deve logo atirar-se ao chão e dizer: - "Eu pronunciei um nome proibido: eu o lanço para dentro das fendas do soalho para me ser possivel comer bem (i. é, estar de acôrdo com os costumes da tribo).

Nova Guiné Inglêsa - nas tribos ocidentais, o principal sabi diz respeito aos nomes de parentela por aliança. No entanto, não se observa o tabu, quando o homem ou a mulher se casa fora da tribo (exogamia), e igualmente quando se acham longe do seu território. A violação do sabi é expiada com o pagamento de multa à pessoa cujo nome foi proferido.

lihas ocidentais do estreito de Tôrres — um homem não menciona os nomes de seu sogro, sogra, cunhado, cunhada, e a espôsa igualmente. Se, por acaso, o mencionar, passa vergonha, 
abaixa a cabeça, e livra-se da humilhação, oferecendo um presente, como multa, ao cunhado ou à cunhada. Se o homem desejar comunicar algo ao cunhado, à cunhada, fa-lo-á por meio de sua espôsa, mas, quando indispensável comunicar-lhes algo diretamente, fa-lo-á breve e em voz baixa.

Nova Bretanha ,na península da Cazela - arquipélago de Bismarque) - mencionar o nome de um cunhado é grande afronta, crime passivel da pena de morte.

Nova Caledônia - vedado a um irmão mencionar o nome de sua irmā, e vice-versa, assim também entre primos e primas.

Ilhas Banques (Melanésia) - muito severos são os tabus sôbre os nomes de pessoas ligadas pelo casamento.

Eslavos do sul - marido e mulher não expõem os nomes de ambos; inventam ou adotam outros.

Ojibuais ou Chipeuaș (América do Norte) - marido e muIher não citam seus nomes.

Omahas (América do Norte) - igualmente, e de seus sogros.

Dacotas (América do Norte) — veda-se dirigir a palavra à mãe de sua mulher, ou de vê-la; a mulher nāo pode viver com o sogro, e evitam proferir o nome de seus pais por aliança.

Nishinam (Califórnia) — o marido não chama a espôsa pelo nome; tal violação causa divórcio.

Australianos - quando uma criança do sexo feminino é prometida em casamento, a partir dêsse momento, fica interditado ao futuro marido e à mãe da criança de se verem ou se ouvirem falar ou de ouvir seus nomes pronunciados por outros. Se violarem tal preceito, envelhecerão prematuramente ou morrerão.

Certas tribos do oeste de Vitória. Austrália, assim entre os Sacais (península da Malaia) — proibido a um homem desposar mulher do mesmo dialeto dêle, e, durante as visitas preliminares, ambos não devem falar a língua da tribo visitada. As crianças aprendem o idioma do pai, e, no mesmo, a mãe lhes fala também, e ao marido na língua dela e o marido the responde na língua 
dêle. Assim se explica há tantos dialetos diferentes conservados em espaço tão limitado, mesmo sem obstáculo físico a impedir as comunicações entre as tribos.

As mulheres jônias não chamavam nunca o marido pelo seu nome, e ninguém devia citar o nome de um pai ou de uma filha durante os ritos de Ceres, em Roma.

$\mathrm{Na}$ Albânia, principalmente entre montanheses, não se permite à mulher chamar o marido pelo nome.

Os Usbeques (Tártaros, Rússia) - chamam à sua mulher - "minha familia", e a mulher ao marido: "meu marido", "meu senhor", "pai de minha filha" (Havers). No interior da Finlândia, perante estranhos, emprega-se, p. ex., anoppi, "sogra", mas na família mamma, que significa pròpriamente "mãe". Em Ingermanlândia, Finlândia, chama-se äiti, "mãe", à sogra, e isä, "pai", ao sogro. A cunhada não designa o cunhado por kyty, mas veikko, forma coloquial de veli, "irmão". A irmã do marido chama-se nato, porém a cunhada trata-a por siso, forma coloquial de sisar, "irmã" (R. E. Nirvi).

Em várias regiões fínicas há o costume de a espôsa, perante estranhos ao marido, só falar dêste mediante pronomes: "o nosso" saiu. ...; "o mesmo" não está. . . Usa-se também "o velho", que, todavia, na linguagem comum, é tido quase sempre como vulgar e grosseiro (R. E. Nirvi).

$\mathrm{Na}$ Carélia, a mulher quando com outra conversa cortêsmente a respeito do marido, refere-se a êle com a designação uros, i. é, "homem" ("meu homem" = "meu marido"), e para "homem" lança-se mão do estrangeirismo mujikka. O fato se verifica não'só no finês como em suas linguas aparentadas" (41-A).

As mulheres mongóis de dialeto ordo evitam os nomes dos sogros e dos cunhados, assim as palavras que se thes assemelham. Neste caso, substituem-nas por sinônimos, e, na falta dêstes, devem mudar a consoante inicial (41-B).

(4) - A) R. E. Nirvi, "Einige Erscheinungen von Wortvermeidung in der Sprache der Frauen" in "Orbis", t. I, n. ${ }^{\circ} 2$, Lovaina, 1952, p. 366.

(4) - B) W. A. Grootaers, "Quelques Tabous Linguistiques" in "Orbis", t. I, n." 1. Lovaina, 1952, p. 86. 
Os Chuvassos (Rússia oriental) denominam a sua mulher "companheira do caminho".

Os Ucranianos dizem simplesmente "minha" à espôsa.

Na Rússia, a espôsa chama ao marido jovem — starik -, i. é, "o veiho".

Há, por tabu de sentimento, repetidos desaparecimentos da palavra "espôsa" e conseqüente uso de substitutos principalmente com a idéia de "mulher".

No Brasil, diz a mulher - "meu marido" (não se tolera meu homem), porém o homem a ela - minha mulher ou minha senhora ou minha patroa. Espôso e espôsa são da linguagem literária.

O lituano móite, "espôsa", era outrora "mãe", vigente, porém, em mótyma.

O romeno femeie, "mulher, espôsa", é evolução de familia.

O nome indo-europeu "sunús, "filho" (consoante Pisani, significava "gerado") foi tabuizado no italo-céltico, assim como o nome "filha", não só em vista da alta significação que alcanzou o filho na sociedade patriarcal (Meillet), senão também por motivo de ordem sentimental (Havers).

O sucedâneo de * sunús foi, no latim, filius = "lactente, mamante", e no céltico " maqqos (donde irl. mac, gaulês mapo-, etc.), e de * dhughaeter, "filha", o lat. criou o feminino de filius, e o céltico veio a criar * enigena = "nascida na (família)" (donde o irl. ingen, gaul. " enigen-, etc.).

$\mathrm{Na}$ india, sunuh, "filho", reservado apenas como vocábulo literário, foi, contudo, interditado na linguagem oral. O sânscrito o substituiu por putrás, aparentado ao lat. putus, "rapazinho, criança".

O desaparecimento de * sunús $e$ * dhugaeter verificouse ainda no letônio, que os substituiu respectivamente por dêls, "rapaz", e mêita, "moça".

O fenômeno se repete na atualidade, pois, p. ex., o lavrador lituano evita dizer mãno sunùs, "meu filho", porém "meu rapaz". "meu jovem" (mãno vãikas). Aquela expressão the soa nobre demais (Trost apud Havers). 
No Brasil, a tendência em usar genitor, genitora e progenitor, progenitora em vez de "pai", "mãe" e "avô", "avó", é devida à emotividade que envolve as palavras pai, mãe, avô, avó. $\mathrm{Na}$ linguagem falada, mas algo desrespeitosa, vai-se generalizando o velho (- "pai") e a velha (= "mãe").

Não raro, as noras tratam a sogra pela designação carinhosa de mãezinha e ao sogro paizinho.

Não há vocábulo documentado do indo-europeu comum para "muiher". O que existia, certamente desapareceu por motivo de qualquer interdição. Assim, o lat. mulier, "mulher" $<$ "* a lactante", * "a que amamenta", é criação relativamente recente.

9. TABUS EM NOMES DE AUTORIDADES - Se os nomes de pessoas vivas, das camadas singelas da sociedade primitiva, e mesmo dos mortos, como veremos adiante, são objetos de tantas apreensões e cuidados, não é para estranhar que maiores precauções se tomem para salvaguardar os nomes de reis, sacerdotes e outras autoridades.

"Os antigos Malgaxes, p. ex., tinham grande respeito a seus chefes; consideravam-nos como "sêres sobrenaturais", e, portanto, "fady", isto é, eram tabuizados (42)".

Os vários rei de Daomé (Africa ocidental) foram conhecidos na Europa por títulos ou "nomes fortes", como dizem os daomeanos. Em geral, são as primeiras palavras de frases misteriosas a descrever certos predicados. Assim, Agaja, 4. ${ }^{\circ}$ rei da dinastia, fazia parte da frase - "E' preciso cortar uma árvore antes de poder lançá-la ao fogo". Tegbwesun, 5. rei, tinha o nome formado da frase - "Ninguém pode arrebatar o pano do pescoço de um touro selvagem".

No reino dos Galas de Ghera (África setentrional), um súdito não pode pronunciar o nome do soberano, sob pena de morte. Deve privar-se das palavras homófonas ou parônimas. Pelo motivo de um rei chamar-se Karre, vedaram-se hara, "fumaça" (substituiu-se por unno), arre, "burro" (empregou-se kulula), gudare, "batata" (usou-se loccio), etc.

(42) Maurice Besson, "Totemismo", trad., Barcelona-Madri, 1931, p. 51. 
Entre os Baímas (África central) pela morte do rei, desaparecem da língua o seu nome e o apelativo de que aquêle se derivou. Dá-se-lhe quase sempre o nome "leão". Um rei foi assim chamado - Mpologoma, porém com a sua morte, o leão ficou sendo kichunchu. Outro rei era Mwenda, "leão", mas com a morte, o leão veio a denominar-se isaga.

Com os Zulus, é tabu não só o nome do chefe da tribo, senão ainda os nomes dos seus antepassados, e tabuízam-se os substantivos apelativos cujas silabas se assemelham. P. ex., por causa do chefe Umfan-o-inhlela, ficou interdito enhlela, "caminho" (substituiu-se por inyatugo); seu pai Manzini obrigou à interdição de manzi, "água" (usou-se mata); seu avô Tshani acarretou o tabu de tshanti, "uma erva" (empregou-se inkosta). Substituiu-se impando, "raiz d'árvore" para nxabo, em vista de sílabas semelhantes com o nome Panda, de um rei zulu. Outros exemplares símiles, devidos à homofonia silábica:

Em Madagascar, a princesa Rabodo veio a reinar (1863); tomou o nome de Rasoeherina. Por êste motivo, soherina, "bicho-da-sêda" passou a zany-dandy, "filho da sêda".

No Siāo (Tailândia) é difícil descobrir o nome do rei; encobria-se por temor aos feiticeiros. Quem o soubesse e viesse a manifestá-lo, seria lançado ao calabouço. Mencionar o rei, sòmente mediante pomposos títulos, como "o Augusto", "o Perfeito". "o Supremo", "o Grande Imperador", "o Descendente dos Anjos", etc. (43). Semelhante fato se dava na Birmânia. Na China, ninguém podia pronunciar, nem sequer escrever o nome do imperador.

Quando um príncipe sobe ao trono de Camboja (Indo-China), seu nome verdadeiro passa a tabu, e as palavras comuns, homofônicas são substituidas. Deixou-se de usar duong. "uma moeda".

(43) Isto lembra os títulos dos imperadores da antiguidade clássica, p. ex., dos Romanos: Dominus, Divus, Nobilis, Augustus, Majestas, Nobilissimus, Fortissimus, Serenissimus, Optimus, Felix, Pius, Divus Augustus, etc. Ver Hahnemann Guimarajes - "Títulos e Honras do Imperador" in "Epigrafia Latina", Rio, 1926, p. 49 e ss.; e C. Cantu, "História Universal", v. VI, trad., p. 214-215. E lembra os modernos: Alteza, Excelência, Senhoria, Mercê, Eminência, llustrissimo, etc. 
em vista do rei Ang Duong. A moeda ficou sendo conhecida por dom.

Se um súdito houver necessidade de citar o nome do rajá de Bolang Mongondo (oeste de Celebes), deve pedir perdão várias vêzes.

Na ilha de Sumba ou Sandalwood (Índias Orientais Holandesas) chamam ao rei pelo nome do primeiro escravo que possuiu na mocidade. O rei o tem como outro eu.

Entre os Sacalavas (Madagascar), morto um rei, os nobres e o povo se reunem em volta do cadáver para escolher o novo nome sob o qual o monarca defunto será, desde então, venerado. A nova denominação deve começar por Andrian ou Andira, "senhor", e acabar por Arriva, "mil", para indicar que o monarca reinava numa nação numerosa. O núcleo do nome seria um epiteto ou expressão sôbre uma particularidade do rei ou do seu reino.

Em vida, o uso do nome do rei obrigava à proibição de pronunciar palavras com sílabas semelhantes. Assim, por um chefe ter o nome Andiramamba, veio causar proibição à palavra mamba, "crocodilo".

Em Madagascar são necessárias palavras especiais para alguém dirigir-se ao rei. Essa linguagem era temporária; usava-se apenas durante a vida do monarca.

Em muitas terras muçulmanas é tabuizado o nome Muhammad, "Maomé", no uso profano. Para isto, há diversas formas afins, além de expressões substitutas como Barakah, "o cheio de graça e bênção". Os turcos atuais distinguem Muhammed, nome do profeta, e Mehmed, Memed, Mehemmed, como profanos (Havers).

Os Carajás do Araguaia estão proibidos de dar o nome de Kobehi, mentor geral da tribo, a qualquer de seus filhos, em virtude da maldição lançada por êle aos descobridores do mundo: "Eu proibo, desobedientes, que jamais se dê, dêsse lado de lá, jamais, o meu nome de Kobehí a carajá nenhum" (44).

Na Grécia, na representaçāo dos mistérios de Elêusis, era delito pronunciar os nomes dos sacerdotes, mas eram aquêles 
confiados às profundezas do mar. Burilava-se, provàvelmente em tabuinhas de bronze ou de chumbo que se lançavam, em seguida, às águas profundas do golfo de Salamina. Tinha-se intenção, sem dúvida, de assegurar o segrêdo impenetrável dêsses têrmos. Contudo, morto o sacerdote, foodia-se dar a público o seu nome.

Os Umbros, provàvelmente tabuizando nomes de autoridades, denominavam os seus altos funcionários com um título etrusco - maru - (alatinado em maro, -onis, n. pr. Maro).

Quando outrora na governança, foi expressamente proibido o uso de Benito, "duce" na Itália, e de Hitler, "führer" na Alemanha (45), e, continuando a tradiçāo secular — Hirohito — imperador do Japāo. No tempo da monarquia chinesa, era tabu o nome do imperador, durante a sua vida (W. J. Entwistle).

Sempre que se menciona o imperador da Etiópia em jornal local, "seu nome deve aparecer no comêço do artigo e nenhum outro pode ser citado antes dêle. Devem ter inicial maiúscula tôdas as referências ao Imperador, inclusive os pronomes" (46).

Segundo registra Havers, o chamado plural de majestade "nós" em vez de "eu" — é, na sua origem, nada mais que um disfarce contra os espíritos malignos, uma vez que o plural favorece a indeterminação (tabu do "eu") (47). Isto lembra a repugnância dos primitivos ou povos naturais em pronunciar seus próprios nomes.

(45) Telegrama difundido pelo mundo afora: "Berlim, 12 - 0 nome de Adolph Hitler e o de outras personalidades partidárias e varōes nazistas são sagrados na Alemanha e protegidos por lei. Quando o nacional-socialismo subiu ao poder em 1933, estabeleceu-se uma verdadeira mania, entre muitos pais, de batizar os seus filhos com o nome do "Führer" ou de Horst Wessel, ou então de chamar às suas filhas de Hitlerik. As autoridades condenaram agora definitivamente êsse hábito e proibiram o uso dêsses e de outros nomes semelhantes" ("A Noticia". Joinvile. 13-1-1938).

(46) John Gunther, "O Drama da Etiópia" in "Seleçōes do Reader's Digest", set. 1954, p. 74.

(47) Não se explica do mesmo modo quando a Divindade fala no plural, p. ex., - "Façamos o homem à nossa imagem e semelhança" (Cên., 1, 26), pois há três pessoas em Deus. 


\section{TABUS EM NOMES RELIGIOSOS (TEÓNIMOS, HIERO-} NIMOS, ETC.) - Deve-se o máximo respeito e veneração ao nome de Deus; é um dos mandamentos: - "Não tomarás o nome do Senhor teu Deus em vão, porque não ficará impune aquê.e que tomar o seu nome por uma coisa vã" (Deuteronômio, $\mathrm{V}, 11$ ). $E$, na liturgia da Igreja católica, após a bênção do SSmo. Sacramento: - "Bendito seja o seu santo Nome!" - "Bendito seja o nome de Jesus!" - "Bendito seja o nome de Maria, virgem e mãe!"

Entre as expressões que, na Bíbilia, se referem a Deus, há estas, simples - Jehová (baseada em Yhwh), Yah, El, Eloah (ou Eloha), Elohim, Adonai, Shaddai, e, estoutras, em locução - Jehová Elohim, Adonai Jehovah, Jehovah Sabaoth, Jehovah Adonai.

De tôdas, Yhwh é tida por a mais sagrada; representa-se em hebraico mediante quatro letras (tetragrama sacro), as quais se chamam, respectivamente, yod, heth, waw heth, isto é, i semiconsoante, $\boldsymbol{h}$ aspirado, $\mathbf{u}$ semiconsoante $\mathrm{e} \boldsymbol{h}$ aspirado.

Se bem que sempre o nome de Deus, sob qualquer forma, fôsse respeitado, venerado e temido, o tetragrama Yhwh foi denominado inefável; ninguém podia pronunciá-lo.

Os rabinos e os padres gregos o qualificavam de "nome por excelência", "nome único", "nome glorioso e terrivel", "nome secreto e misterioso", "nome da substância". "nome próprio". "nome separado", "nome escrito e não lido", etc.

Baseiam os rabinos a interdição de pronunciar o tetragrama na passagem do Levítico, XXIV, 16, entendido em sentido rigoroso: "O que blasfema o nome do Senhor, seja punido de morte". Ora, sucede que o verbo "blasfemar" (nqd) foi lido como o verbo homônimo (nqd), o qual tem o sentido de "pontuar, designar", i. é: "O que designar (dar a conhecer) o nome do Senhor (Yhwh), seja punido de morte" (48).

Provàvelmente essa leitura foi admitida, em vista de, no mesmo versículo, haver iá citada a idéia de "blasfemar": "E o

(48) F. Vigouroux, "Dictionnaire de la Bible", t. III, Paris, 1903, s. v. Jéhovah. 
que blasfemar o nome do Senhor, seja punido de morte; todo o povo o apedrejará, quer seja cidadāo, quer seja forasteiro. O que blasfemar o nome do Senhor, seja punido de morte".

No dizer de um rabino, Paulo de Burgos, sòmente os sumos sacerdotes tinham o direito de proferir o nome inefável, ciando abençoavam solenemente o povo, mas no Tálmude se declarou que só o pontifice podia fazê-lo, quando entrava no Santo dos Santos, no dia da expiação ou iom kippurim.

Conforme Filon o judeu, membro de uma familia sacerdotal, não se externava êsse nome em voz alta, mas baixa. Destruido o templo de lerusalém, nunca mais foi pronunciado (49).

Visto que os caracteres hebraicos são desacompanhados de vogais, há um problema que, parece, até agora subsiste: - Como se pronunciava exatamente Yhwh.

Quando um israelita deparava, na leitura dos Livros Sagrados, com êsse nome inefável, deveria substitui-lo por Adonai, "meus Senhores" ou por Elohim, "Deuses", verdadeiro "pluralis magnitudinis". E, para advertência, os massoretas lançaram mão do seguinte expediente: o emprêgo das vogais constantes na palavra Adonai, i. é, YaHoWaH ou, com -e- breve, em lugar do -a-: YeHoWaH; se ao tetragrama precede Adonai, inseriam-se as vogais de Elohim, i. é: YeHoWiH. Destarte, admite-se que a pronúncia de Jehovah nāo tem fundamento senão nessa convenção.

$O$ pe. F. Vigouroux, após considerações várias, crê poder concluir que "le tétragamme divin se prononçait Yahvéh; ce qui, transcrit en grec, donne labé" (50).

Por outro lado, a existência das formas abreviadas -yahu, yau ("sufixantes") e yeho-, yo- ("prefixantes"), principalmente como elementos de antropônimos compostos, provam que o tetragrama era proferido e muito comumente. Pode ser que, no entanto, segundo Vigouroux, a forma completa Yahveh tenha sido evitada pelo respeito, como Eloah e Elohim, cujo elemento de composição é o abreviado El (51). 
M. Horowitz, autor de uma gramática hebraica (52), diz que o nome de Deus - Adonai ou Elohim - só se pronuncia na oração, e, em tôda outra ocasião, para não profaná-lo, diz-se apenas Ha Shem, "o Nome". ou, então Adoshem e Eloqim, deformaçōes ou, melhor, disfarces daqueles nomes.

Apesar do que se afirma com referência à pronunciação das vogais intercaladas no tetragrama $\mathbf{Y h w h}$, na ciência cabalística medieval só o Ba'al Shem, "senhor do Nome", era conhecedor das vogais tidas como secretas, o que the concedia extraordinários poderes mágicos (53).

Os patriarcas davam às vêzes à Divindade alguns qualificativos, como El Olam, "Deus Eterno", El Roi, "Deus da Visão", ou, então, designações que lembravam um fato histórico: El Bethel, "O Deus de Betel", "O Terror de Isaque", "O Rochedo de Israel".

Certamente foi Adonai, o qual se deve traduzir por "Meu Senhor", que favoreceu a substituição de Yhwh para Kyrios, "Senhor", entre os judeus helenizados do Egito, que traduziram a Bíblia em grego, aí pelo séc. Ill a. C., e daí as traduções Dominus, no latim, Senhor, no português, etc. (54).

(52) "Manuel d'Hébreu", Cailly-sur-Eure, 1945, p. 59-60.

(53) Mário Pei, "The Story of Language", Filadélfia e Nova lorque, 1949, p. 249.

(54) A. Meillet, "Linguistique Historique et Linguistique Générale", t. 1. Paris, 1926 , p. 346-347, e repetição no $t$. II, 1938, p. 39-40.

De passo, uma pergunta - Qual a significação primitiva de leová?

Pelas palavras do próprio Deus (Exodo, III, 13-14), o tetragrama significa

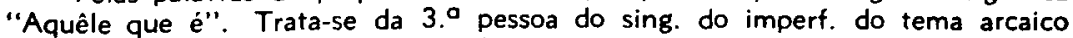
hwh, "ser", muito provàvelmente de origem semítica. O obstáculo que apresentam, é à idéia muito abstrata para tāo antigos tempos ("Everyman's Encyclopaedia", 3.0 ed., 1951, t. VII, s. v. Jehovah, p. 743).

Se tivermos presentes as formas por que se podem originar os verbos copulativos ou neutros nas diversas linguas, então concluiremos que lá também não há abstração. Conforme Trombetti, entre um sujeito e um adjunto predicativo põe-se um pronome (que serve de cópula, raiz do verbo copulativo), repetição do sujeito, e, mais tarde, êsse pronome pode assumir o caráter de verbo (verbo copulativo), com a adjunção de desinência (línguas sufixantes) (Ver A. Trombetti, "Elementi di Glottologia", Bolonha, 1923. p. 2191.

Conclusão: hwh poderia ter sido, primitivamente, um pronome.

Trombetti apõe ao hebraico jahu-é. "Deus" etc., o basco jau-n, jau-r, "senhor", jau-be, ja-be, "patrão", e o abcazo (eáusico) ah, "senhor". ("Le Origini della Lingua Basca", Bolonha, 1925, p. 130).

"O nome leHovah, diz I. Quintela Vaz de Melo, deriva-se do verbo cal- 
Ao passo que os evangelistas S. Marcos, S. Lucas e S. João empregam como única expressão, reino de Deus, o evangelista $S$. Mateus, cuja boa-nova é dirigida especialmente aos judeus, usa como substituição equivalente, - reino dos céus (aramaico malkuta dishemajja) - "pela preocupação rabínica de evitar o emprêgo do nome de Deus" (55).

E' também por veneração e respeito que não se encontram, senão rarissimamente, entre nós, pessoas com o nome de Jesus. Preferem-se derivados, como Jesuíno,-a, Cristino,-a, êste como substituto de Cristo, que, todavia, se emprega como sobrenome.

$\mathrm{Na}$ Espanha e nas repúblicas hispano-americanas, se bem que se use Jesus como nome de pessoa, é. não obstante, evitado o nome de Maria, o qual se substitui, pelas diversas invocações Amparo, Asunción, Concepción, Dolores, Encarnación, Mercedes, Pilar, Rosario, Soledad, etc. (56).

Como se deve fugir às imprecações ou aos juramentos em nome de Deus, tem havido, em diversas línguas, deformações voluntárias em frases exclamativas, as quais, contudo, não deixam de ser desrespeitosas:

No francês: corbleu, morbleu, parbleu (= "par Dieu"), pardi, palsambleu, pardienne, parguienne, sacrebleu, têtebleu, tudieu (= "vertu Dieu"), etc., quase todos arcaicos (57).

daico HaVah = Aquêle que é eterno. A silaba le indica o futuro; Ho significa o presente, e VaH simboliza o passado. Sem princípio nem fim, é o Princípio e o Fim de tudo quanto existe". ("Ignotum per Ignotius", B. Horizonte, 1955, p. 147-148).

Outros étimos propostos em A. Bertholet e H. F. von Campenhausen, "Woerterbuch der Religionen", Estugarda, 1952, s. v. Jahve. Ai se afirma que é etimologia popular o constante no Ex., III, 13-14, na suposição de que o próprio Deus não quis manifestar seu verdadeiro nome.

(55) G. Ricciotti, "Vita di Gesù Cristo". Milāo - Roma, 1941, p. 131. - Deve-se à tradução grega a expressão reino de Deus que se acha também em Mateus (1d., ib., p. 130, nota)

(56) João Ribeiro. "Curiosidades Verbais". 1927, p. 121.

(57) O Bloch — Wartburg. "Dict. Étim. de la L. Française". 2.0 ed., 1950, s. v. Dieu. - A. Dauzat, "Dictionnaire Étymologique". 4." ed. s. v. Dieu. 
No inglês (a maioria inusitada). by gog, by golly, by gum, by gosh, drot, drat, gad, dad, bob, gough, gummy, cock, great scott, bloody, gee-whiz (= "Jesus") (58), além de egad, good, gee, snails, zounds, ods bodikin, Cripes (= "Christ"), etc. (59).

No alemão: potztausend, pott sallerment, Herrje (= "Herr Jesus!"). No dialeto renano: Hott, Kotz, Pott, Schnott. No médio baixo alem.: Golt, Golbe, Goldke, Golle, Goltke. No dialeto eslévique-holsácio: Gotts, Sott. No alemão-suiço a locução optativa Gott wolle passou a Gotwell e dai a Gottel e Goppel. Bigopp, Bigost, em vez de Bigott (= "por Deus!"). No dialeto hesse nassau: Cuterei (= "Cuter Heiland"), Liberei ("Lieber Heiland").

$\mathrm{Na}$ língua sérvia: bora mi, broda mi, gloga mi (= "Boga mil!" "Deus meu!').

No italiano: Perdinci, perdino (= "per Dio!"), per mio, Cribbio (= "Cristo!"), per Crispo.

No espanhol: Voto à brios, juro à brios (=... "Dios!"), pardiez, parbliós, parbriós, parbrioste, pardiobre.

No galego: pardiós, pardiola, pardiolas, pardioliña(s).

"Os nossos antigos, diz Leite de Vasconcelos, usavam interjetivamente a expressão pardês, isto é, "por Deus!", espécie de jura. Para evitarem a profanação do nome de Deus, empregando em sentido ordinário uma expressão solerie, e também porque a jura era freqüentemente falsa, desfiguravam aquela expressão em pardelhas" (60). Outros desfiguramentos do port. arc. pardeos são pardéo, pardicas, pardelhas $(60-\mathrm{A})$.

Parece que o nome da divindade germânica Odin era evitado, mais por temor do que por veneração; Odin significa "o furioso", e foi, dizem, o inventor das runas e criador da magia. Possuia, na mitologia nórdica, numerosíssimas denominações, mais de quarenta, uma das quais sinônima daquele - Crimr - se se ba-

(58) O. Jespersen, "Humanidad, Nación, Individuo", p. 226.

(59) W. Havers, o. c., $\$ 50$.

(60) "Liçōes de Filologia Port.", 2. ${ }^{\circ}$ ed., Lisboa, 1926, p. 400.

(60 - A) Camões evitou o nome Deus quando no "Filodemo" expressou - "Justiça, pelo corpo de tal!" $\left(\mathrm{V}, 2^{\circ}{ }^{\circ}\right.$. 
seia de fato nos correspondentes islandês grimmr, "terrível" e dinamarquês grim, idem. Outras com sentido inócuo: "chapéu amplo" (referência à abóbada celeste), "barba comprida". Herjann (que lembra o gótico harjis, "exército"; é o protetor dos guerreiros); Hialmbert (talvez signifique "capacete" — hjalmr — "que brilha" - bert; cp. "chapéu amplo").

Outros nomes são, para Jespersen, apenas sons desprovidos de significado (estoglossias): "Aparte del simple sonido, que en cierto grado también nos agrada a nosotros, sin duda, para los antiguos escandinavos tenian un valor místico, mágico, semirreligioso o completamente religioso. Por retahilas de sonidos de esta clase trataban de conjurar los malos espíritus y dominar los poderes misteriosos de la naturaleza" (61).

No panteão dos Vedas havia o ser único, o espírito divino, "dont on ne parlait qu'avec une religieuse terreur, et dont il était interdit de prononcer le nom mystique figuré par le monosyllabe composé de trois lettres représentant ses trois attributs de création, de transformation et de conservation" - Aum (62). Davam-lhe os sábios e poetas mais de um nome.

A divindade egípcia Ra possuia várias denominações, porém com uma das quais se tornava potentíssima sôbre os outros deuses e os homens; tal nome não era conhecido por ninguém. Conta-se que Ísis chegou a fazer que Ra lho declarasse.

Cria-se aquêle que possuisse o verdadeiro nome, possuiria a essência do ser divino ou humano. e podia forçar mesmo uma divindade a obedecer-lhe: "L'art du magicien consistait donc à obtenir des dieus la révélation de leur nom sacré, et il ne reculait devant aucun moyen pour atteindre ce but" (63).

Num papiro egipcio foi encontrada esta adjuração ao deus Tifão: "Eu te invoco pelos teus nomes verdadeiros, em virtude dos quais tu não podes recusar ouvir-me". Em outro, o mágico ameaça Osíris de pronunciar em alta voz o seu nome no pôrto de Busíris, se o mesmo não atender a seus votos (64).

(61) O. Jespersen, "Humanidad...". p. 239-240.

(62) L. Jacolliot, "Les Traditions Indo-européennes", 2.0 ed., Paris, 1876, p. 299-300.

(63) J. G. Frazer, "Tabou. . ", p. 318.

(64) Id., ib., p. 319. 
Em Lucano, a maga tessalonicense que consultou Sexto Pompeu antes da batalha de Farsália, ameaça-lhe chamar as Fúrias mediante seus verdadeiros nomes, caso êle não fizesse o que ela ordenava (65).

Entre os Árabes da África do norte, o poder do nome é tal que, quando os nomes próprios são conhecidos, os djins não podem deixar de atender; êles são os servidores dos nomes mágicos (Frazer).

E' proibido expressar o nome Yo, a máxima divindade entre os Máoris (Nova Zelândia), a não ser no canto da invocação, e, geralmente só em recintos fechados. Como designações noas. empregam-se "o Alto", "o de além", etc. (Havers).

Os Temáuqueles, habitantes da Terra do Fogo, raramente falam de seu deus, e, quando necessário, referem-se ao "habitante do céu", "aquêle que está no céu" (Havers).

"Haipuku, diz Harald Schultz, é uma das divindades na religião umutina". "Os Umutinas (Mato Grosso) não gostam que se the repita com frequiência o nome. Esclarecem ser o ancestral da tribo" (66).

Houve expressões referentes a divindades que, pelo respeito, não deviam vir no caso genitivo, o que podia ser sentido como uma ofensa, donde o recurso de apresentá-las adjetivalmente (Havers). Em grego: Diôn, ómma, literalmente "jovial ôlho", i. é, "ôlho de Júpiter ou Zeus". O adjetivo diôs, diâ, diōn, "relativo a Zeus". com a idéia de "divino", usava-se em genitivo, falando-se de deusas, nunca de deuses (67): dia theáon, "divina entre as deusas". i. é. "muito augusta". Quer dizer que êsse qualificativo se reservava exclusivamente à divindade suprema, porque, então, mantinha a idéia de "relativo a Zeus".

Em latim: flamen dialis, "flâmine de Júpiter", como jovialis stella, "estrêla de Júpiter" ou " a constelação Júpiter".

(65) Lucano, "Pharsale", VI, apud I. G. Frazer, o. c., P. 319.

(66) $\mathrm{H}$. Schultz, "Vinte e Três Indios Resistem à Civilizaçäo", S. Paulo, s/d (1954), nota 20, p. 77.

(67) A. Bailly, "Dic. Grec-Français", s. v. 
As cidades antigas possuiam divindades protetoras.

Os Assirios, parece, interditavam os nomes misticos de suas cidades, que tais eram os dos deuses.

Quando as legiōes romanas sitiavam uma cidade, apressavam-se os sacerdotes em dirigir oraçōes rituais ou encantamentos à divindade protetora do lugar, convidando-a a deixar a cidade e a passar aos Romanos. Assegurava-se-lhe que seria bem tratada, ou melhor do que anteriormente (68).

O nome principal da divindade protetora de Roma estava envolta no mais profundo mistério. Temia-se que os inimigos da República pudessem atraí-la, fazendo-a que abandonasse Roma: "Os romanos imaginaram um meio que lhes parecia mais seguro: conservavam secreto o nome principal e do mais poderoso dos seus deuses protetores; pensavam que não podendo nunca invocar o deus pelo seu nome, êste nunca sairia do seu lado e a cidade nunca poderia ser tomada" (69).

Além disto, para afastar esconjurações maléficas, a própria cidade possuia um nome sagrado, secreto, que jamais devia ser pronunciado ou escrito, nem mesmo nas cerimônias religiosas. A menção dêsse nome como daquele acarretava a pena de morte.

Tão escrupulosamente foi isso observado, com respeito à cidade de Roma, que até hoje se ignora qual fôsse. Conjeturaram que talvez fôsse Quiris, de que se derivou quirites, "cidadão romano", mas, parece, destituído de traço da significação primitiva (70), ou, então, fôsse provàvelmente Valentia.

Na linguagem religiosa pagã, por prudência, usaram-se, para o sacrificio, expressões genéricas ou abreviadas:

Latim fácere = ágere = operari, isto é, "sacrificar", "fazer sacrifício a". Do último verbo se fêz o alemão opfern, "sacrificar, imolar". Grego: rhézein, "sacrificar", da idéia primitiva "fazer" com objeto: rhézein hierèn hekatómben ou hierà rhézein $=$ lat. sacra fácere).

(68) Fustel de Coulanges, "A Cidade Antiga", v. I, 2. ${ }^{\circ}$ ed., 1920, trad., p. 266.

(69) Id., ib., p. 269. Segundo Sérvio, a lei pontifical proibia chamar os deuses romanos por seu nome: "Indigetes dii quorum nomina vulgari non licet" (Festus).

(70) A. Dauzat, 'La Vie du Langage". 4. ed., 1929, p. 242; "La Philosophie du Langage". 1932, p. 24-25; O lespersen, "Humanidad, Nación, Individuo", p. 226. 
O umbro asa-, "altar", é um "arcaísmo ritual"; evitou-se, conscientemente, o rotacismo, visto tratar-se de têrmo sagrado, de uso religioso. Não poderia, em consequiência, sujeitar-se à evolução fonética, profana (71).

11. CRISTIANISMO - Pelo respeito à Eucaristia, passaram, na Grécia, as palavras ártos, "pão" e oînos, "vinho", a sair do uso corrente, substituídas respectivamente por psomi ["fração"] e krâsi ["mistura"], reservando-se aquelas para uso religioso (Jespersen).

No latim dos primitivos cristãos, usava-se o adjetivo dominicum a significar "culto eucarístico e comunhão", com elipse respeitosa de convivium, epulum, officium, sacrificium (Dölger apud Havers). Bastava sancta (decalque no gr. tà hágia) para compreender-se "eucaristia" (em vez de sancta eucharistia). Dizem igualmente os Árabes cristãos - al kaddás — "o santo", isto é, "o santo sacrifício".

O latim verbum não subsistiu nas línguas românicas por haver sido consagrado como a palavra de Deus (port. Verbo, latinismo, para se avaliar o sentido primevo de desgraça, "perda da graFicou em seu lugar parábola ( $>$ palavra, palabra, parole), que também é de origem cristã (Jespersen, Ernout, Meillet).

Na Alemanha, Abendessen, "ceia", Abendmahlzeit, idem. e, na Austria, Nachmahl, idem, tomaram, na linguagem comum, - lugar de Abendmahl, ora reservado à linguagem da religião "ceia do Senhor" (Jespersen).

E' preciso ter presente a importância da graça no Cristianismo, para se avaliar o sentido primevo de desgraça, "perda da graça santificante, infelicidade pelo pecado", donde o adjetivo desgraçado. Tão forte é êste que se modificou eufemisticamente em desgranhado, disgranhado, desgranido, disgranido, disgramado, disgrenhado, disgracido, disgra, grenado, disgranhento, disga, nisga (7) - A), disgranhudo.

(Continua) 